\title{
"SÁBADOS COM DELEUZE": IMAGENS NA ESCRITA E ESCREVER PELO FORA ENTRE ARTE, PESQUISA E EDUCAÇÃO
}

Cristian Poletti Mossi ${ }^{(*)}$

Marilda Oliveira de Oliveira ${ }^{(*)}$

\section{IDEIAS QUE CIRCULAM NESTE TEXTO ${ }^{1}$ (OU CINCO VETORES PARA SE ORIENTAR)}

1. A de que não há separação entre teoria e prática;

2. A de que a filosofia, assim como a arte, existe para mobilizar o pensamento e não para representar um pretenso ideal de mundo. E a educação pode ser um lugar para criar;

3. A de que um coletivo, uma matilha, um bando, é um agenciamento de vozes singulares que perdem a autoria;

4. A de que a pesquisa é eminentemente um exercício perigoso, mas que - assim como a filosofia e a arte - em alguns momentos (talvez, na tentativa de não falhar) se enrijeceu em demasia. Se tornou séria demais;

5. A de que não é necessário abandonar certas certezas para produzir incertezas, ou de que as incertezas não precisam se legitimar como novas certezas para poder se afirmar enquanto formas outras/possíveis de pensar.

\footnotetext{
(*) Professor Adjunto da Faculdade de Educação da Universidade Federal do Rio Grande do Sul (UFRGS) junto ao Departamento de Ensino e Currículo. Possui Doutorado em Educação (2014) pelo Programa de Pós-Graduação em Educação (PPGE), na linha de pesquisa Educação e Artes e Mestrado em Artes Visuais (2010) pelo Programa de PósGraduação em Artes Visuais (PPGART), na linha de pesquisa Arte e Cultura, ambos pela Universidade Federal de Santa Maria (UFSM/RS) e com financiamento integral da CAPES. Graduação em Desenho e Plástica - Bacharelado e Licenciatura Plena (2004/2007), Pós-graduação - Especialização em Design para Estamparia (2008) na mesma instituição.

${ }^{(* *)}$ Professora Associada do Programa de Pós-Graduação em Educação da Universidade Federal de Santa Maria, RS, Brasil. Orientadora de Mestrado e Doutorado na Linha de Pesquisa em Educação e Artes, LP4 do PPGE, da UFSM. Doutora em História da Arte pela Universidad de Barcelona, Espanha. Líder do GEPAEC - Grupo de Estudos e Pesquisas em Arte, Educação e Cultura da UFSM e Editora-chefe da Revista Digital Laboratório de Artes Visuais.

${ }^{1}$ Parte deste texto foi por nós publicada nos anais do $22^{\circ}$ Encontro Nacional da Associação Nacional dos Pesquisadores em Artes Plásticas - Anpap (2013) sob o título "Inscrever imagens na escrita, escrever pelo Fora: impactos da filosofia de Deleuze \& Guattari nas pesquisas em educação" e tinha, na ocasião, outro foco de análise mediante os conceitos aqui tratados.
} 


\section{AOS SÁBADOS: DELEUZE}

Há mais ou menos dois anos formamos um coletivo - o 'Sábados com Deleuze'2 - de professores e/ou artistas e/ou pesquisadores que se encontram aos sábados (um sábado ao mês) no Laboratório de Artes Visuais (LAV) do Centro de Educação (CE) da Universidade Federal de Santa Maria para estudar um autor que tem nos afetado e nos ajudado a produzir nossos fazeres nos mais diversos âmbitos entre arte, pesquisa e educação: Gilles Deleuze.

Temos estudado cronologicamente sua obra e, sempre que possível, feito conexões com os intercessores de seu pensamento, tais como Francis Bacon, Foucault, Nietzsche, Spinoza, dentre outros. Nessa extensa lista de obras não ficaram de fora os escritos produzidos por Deleuze junto a Guattari, tão importantes para o conjunto de sua produção e para os conceitos que o autor passa a criar depois desse fecundo encontro.

Inúmeros são os impactos desse estudo para grande parte dos envolvidos no grupo, tanto nas formas de pensar uma aula, uma obra artística, uma investigação ou mesmo a própria vida. Contudo, nesse texto especificamente, optamos por evidenciar um recorte muito preciso: como temos pensado os impactos de alguns de seus conceitos na produção de pesquisas em educação e, sobretudo, como temos trabalhado com imagens nessas pesquisas, não como reforço ou decalque de ideias narradas em forma de texto, mas como disparadoras de tramas discursivas que excedem, ampliam, tensionam a escrita.

Temos buscado produzir, como sugere o título do potente e provocativo livro organizado por Cristiana Callai e Anelice Ribetto (2016), "uma escrita acadêmica outra” e, por conseguinte, uma utilização de imagens também outra nessas investigações.

Quando escrevemos sem dogmatismo - como quem pesquisa os movimentos contraditórios da vida, abrimos mão da sisudez das certezas que precisariam ser ensinadas, do tom magistral de quem é o dono da verdade, da defesa do que já aprendemos, para colocarmo-nos dentro e fora do âmbito do já vivido e comprovado e, assim, arrancados dos limites de nós mesmos -, arriscamo-nos a tatear atalhos e caminhos e a balbuciar outras palavras. Então a escrita se faz como uma experiência que nos toma de curiosidade e prazer, expondo-nos ao risco e à aventura de travessias surpreendentes (LINHARES, 2016, p. 8).

Nesse sentido, o objetivo do texto não é, de modo algum, impor certa prática como mais apurada frente a outras tantas as quais, embora não compatíveis com o exercício que temos feito,

\footnotetext{
${ }^{2}$ Em sua maioria o coletivo é formado por professores e (ex-) estudantes da Linha de Pesquisa Educação e Artes (LP4) do Programa de Pós-Graduação em Educação (PPGE) da Universidade Federal de Santa Maria.
} 
são de extrema contribuição para o campo da educação. Tampouco desejamos produzir algum tipo de polaridade (nós e os outros). Trata-se apenas da dissecação e exposição de um modo possível de pensamento que tem sido praticado, exercitado, cartografado pelo referido coletivo, ou ainda, do compartilhamento de como temos visualizado e proposto dentro da academia jeitos outros de produzir pesquisa tramando arte e educação.

\section{DELEUZE \& GUATTARI E AS PESQUISAS EM EDUCAÇÃO: QUE GIRO É ESSE?}

Nos estudos que temos efetuado em profundidade no coletivo Sábados com Deleuze, pudemos constatar que nem Deleuze em sua obra solo, nem Deleuze \& Guattari em sua obra conjunta, escreveram diretamente sobre a área da educação. Contudo, nos últimos anos, o pensamento inaugurado pelos autores composto por práticas, noções e conceitos, têm inspirado diversas pesquisas decorrentes das ciências humanas onde se incluem as investigações referendadas à área da educação. Poderíamos arriscar afirmar, inclusive, que a criação filosófica instaurada por esses autores, provocam um giro considerável no modo não só de fazer pesquisa (esfera metodológica), mas também no modo de pensá-la e fundamentá-la (esfera epistemológica). Desse modo, inspirados por Corazza (2012), nos perguntamos: quem são esses autores e o que, mesmo sem querer, querem do campo educacional?

De forma bastante genérica, pontuamos que, em uma iniciativa anti-cartesiana, os autores (por exemplo, nas obras Mil Platôs, O que é a filosofia? e Conversações) deslocam-se do cogito 'penso, logo existo' - afirmativa que coloca o Eu plenamente consciente, autônomo e unívoco no centro dos processos cognitivos frente a uma suposta realidade fixa e estável - para explorar outras estruturas do pensar e, claro, outros modos de produzir a própria filosofia enquanto atividade inventiva/criativa, assim como seriam a arte e a própria ciência.

Mas, que estruturas e modos seriam esses? Caminhemos à guisa de possíveis (e provisórias) respostas... Para os autores (em uma tradição teórica que parece perseguir o que anteriormente já fora de algum modo iniciado por Spinoza, Nietzsche, Blanchot, Foucault e outros), a filosofia, distante de uma estruturação de modelos conceituais que se destinam a representar a realidade vista como algo fixo, estável, historicamente linear e uniforme - buscando assim planos superiores de apuramento cognitivo e de transcendência frente à mesma, se proporia primordialmente à criação de conceitos sobre um plano de imanência ${ }^{3}$. Ou seja, afirmando que pensar é também criar,

\footnotetext{
${ }^{3}$ Enquanto a transcendência seria o depois, o além-mundo, o paraíso prometido onde nunca se chega, a imanência seria a horizontalidade do plano do aqui e agora, do presente que se atualiza e que é comprimido na iminência de algo que está sempre por vir e, ao mesmo tempo, que sempre acabou de acontecer.
} 
inventar o objeto pensado e o próprio observador - que não mais se dissociam -, cunhar-se-iam realidades plurais e flexíveis, atravessadas por multiplicidades e intensidades minoritárias (DELEUZE \& GUATTARI, 1992a).

Para a filosofia deleuzeana/deleuzeguattariana, diferentemente do que se observa na filosofia clássica, o pensamento não pode ser visto como algo natural e inato ao ser humano, mas como algo que precisa ser acionado, disparado, violentado frente a diferentes encontros e afecções.

Pensar (...) é um exercício perigoso. (...) é sempre seguir a linha de fuga do vôo da bruxa. (...) não pensamos sem nos tornarmos outra coisa, algo que não pensa, um bicho, um vegetal, uma molécula, uma partícula, que retornam sobre o pensamento e o relançam (DELEUZE \& GUATTARI, 1992a, p. 58-59).

Sem dúvida, a virada mencionada reinventa não somente os modos de produzir a filosofia, mas também as possibilidades de compor e produzir as pesquisas no campo das ciências humanas que se dispõem a transitar por tais concepções epistemológicas e metodológicas. Sobretudo, redimensiona o que seria o próprio pensamento, o próprio ato de pensar, já inseparável do corpo e dos afetos que o mobilizam.

No caso das investigações na área da educação, em diversos exemplos que poderíamos aqui citar e que não serão mencionadas visto que não é o intuito deste texto fazer algum tipo de 'denúncia' a respeito de certo modo de produzir investigações, tais pesquisas, ainda amplamente embasadas em táticas oriundas das ciências naturais e exatas, tradicionalmente e amplamente mencionadas como instrumentos de captura e transformação do real, frequentemente são associadas a operações pseudo-heróicas que se destinariam a tornar seu objeto investigado melhor e mais apurado, mediante estratégias traçadas após seus resultados vistos sempre como verdades científicas confiáveis. Nesse aspecto, sujeito e objeto seriam instâncias completamente diferentes, separadas e fixas. Chamaremos essas pesquisas, de acordo com Mossi (2014, p. 28), de pesquisas Majoritárias, “compreendendo Maioria em Deleuze \& Guattari como um estado de dominação em relação ao qual estão à margem as minorias".

Portanto, em se tratando das pesquisas Majoritárias, o universo das imagens/visualidades parece se deter somente à mera ilustração de conteúdos pesquisados e à representação, reafirmação de concepções escritas. Raramente são vistas como instâncias que possuem alguma carga discursiva própria, legítima e, no máximo, buscam 'dar conta' do que a escrita não conseguiu elucidar. Ou seja, são vistas não como experiências diferenciadas que poderiam dialogar com ou tensionar o texto escrito, mas como sinônimos contíguos que facilmente valeriam um pelo outro. Atendem, 
portanto, a um papel meramente secundário na construção dos textos da investigação e do próprio formato que é apresentado como produto final da mesma.

É nesse contexto que pretendemos, neste artigo, situar o trabalho que temos feito enquanto coletivo (OLIVEIRA, 2015), que estuda e pesquisa junto, o qual, sob o impacto da filosofia deleuzeguattariana, busca possíveis torções mediante certa lógica majoritária (MOSSI, 2014) de produzir e apresentar pesquisas no campo educacional, procurando operar com conceitos da filosofia de modo não representacional, como criações de mundos possíveis sobre um plano de imanência e posicionar as imagens como parte legítima de sua construção discursiva, intentando assim ofertar ao leitor interstícios para que se posicione e produza nexos singulares frente ao texto como um todo (escrita/imagens).

Para tanto, após explorar brevemente alguns dos interesses investigativos pautados pelo coletivo Sábados com Deleuze, relacionando-os à prática do Corpo-sem-Órgãos proposta por Deleuze \& Guattari (2012a) a partir de Artaud (1947) e aos conceitos de sistema pontual (arborescente, molar, memorial) e sistema linear (rizomático, geográfico, anti-memorial), pontuados por Deleuze \& Guattari mais especificamente no Platô 10 do quarto volume (2012b) da obra Mil Platôs, situaremos a discussão sobre a afirmação que Deleuze fez em entrevista a Christian Descamps, Didier Eribon e Robert Maggiori (Libération, 23 de outubro de 1980) publicada em seu livro Conversações (1992b), de que Mille Plateaux (no Brasil, traduzido para Mil Platôs) - escrito conjuntamente com Félix Guattari - seria, segundo o autor, um "livro ilustrado" onde a imagem ocupa um papel primordial (embora não central, essencial) no mapeamento de sua produção de conceitos e nas circunstâncias que cercam tal ação.

Ambas as noções, dentre outras, nos ajudam no coletivo Sábados com Deleuze a pensar sobre nossos trabalhos de pesquisa e se entrecruzaram a fim de implementar na produção das Dissertações e Teses uma construção (escrita/imagética) em consonância com uma "experiência do Fora”, apontada por Deleuze em seguimento à Blanchot e Foucault (LEVY, 2011). Ou, como está pontuado no título deste texto, uma escrita pelo Fora, em direção a ele e que dele “(...) retornamos com os olhos vermelhos (DELEUZE \& GUATTARI, 1992a, p. 58-59)”. Tais idas e vindas se configuram não como movimentos objetivos (temporais/espaciais), mas como movimentos infinitos que ocorrem como devires, a todo o tempo, ainda que estejamos fixados no mesmo lugar. Movimentos de desterritorialização que logo nos territorializam e se voltam sobre nós mesmos instaurando sobre o espaço liso do Fora uma dobra enquanto modo de subjetivação singular. 


\section{INVESTIGAR NO CAMPO DA EDUCAÇÃO: UM CORPO-SEM-ÓRGÃOS E EDUCAÇÕES POSSÍVEIS, SISTEMAS PONTUAIS E LINEARES}

Imaginemos, sob o impacto da filosofia de Deleuze e Guattari, o campo educacional, em especial as investigações que se constituem nele (sobretudo as pesquisas Majoritárias mencionadas anteriormente), enquanto conjuntos de agenciamentos territoriais estratificados (DELEUZE; GUATTARI, 2011). Camadas e camadas endurecidas as quais, segundo os próprios autores, não são completamente fixas, estáveis, apresentando sempre possibilidades de desestratificação e desterritorialização constantes em direção a um Fora absoluto (um Todo aberto), a um plano de consistência ou Corpo-sem-Órgãos sobre o qual se formam, como coagulações, tais estratos.

Esse Fora/Corpo-sem-Órgãos, portanto, formado somente por intensidades selvagens, movimentos infinitos, devires e linhas de fuga, constitui "ao mesmo tempo o que deve ser pensado e o que não pode ser pensado (DELEUZE; GUATTARI, 1992a, p. 78)", ou ainda o não pensado do próprio pensamento. Quanto aos estratos compostos como mantas sobre ele, segundo os autores, apresentam sempre, por um lado, formas de conteúdo enquanto misturas de corpos e, por outro, formas de expressão enquanto misturas de expressos incorporais (DELEUZE; GUATTARI, 2011). Tais articulações, embora não se confundam uma com a outra, estão sempre em pressuposição recíproca, interferindo uma sobre a outra.

Se nos reportarmos ao campo educacional e, mais especificamente, às investigações Majoritárias produzidas no mesmo, como parte constituinte desses agenciamentos territoriais estratificados, passaremos a pensá-los sempre compostos por formas de conteúdo (agenciando indivíduos, materialidades, sujeitos, espaços, lugares, conjuntos arquitetônicos, entre outros, que produzem saberes e os colocam em prática) e por formas de expressão (teorias, métodos, discursos, semióticas próprias, entre outros, os quais são cuidadosamente tecidos a fim de interferir diretamente sobre os corpos envolvidos em tais ações), as quais estão sempre prestes a se desestratificar.

Sendo assim, ainda que pareça um equívoco de grafia na formatação deste texto, o atual subtítulo traz uma Educação, com letra maiúscula, e educações, no plural e com letra minúscula, propositalmente. Trata-se de pensar que há uma Educação - enquanto campo legitimado e marcada por diversos códigos, normativas e conceitos pré-existentes (enquanto conjunto de agenciamentos territoriais estratificados) - e, por assim dizer, a possibilidade de instaurar nas brechas dessa Grande Educação, educações possíveis - estratégias marginais descompromissadas com universalismos e verdades absolutas, intentando possibilidades de abertura para o Fora, de seguir linhas de fuga para o impensado, para o não estratificado e transitório, para um devir minoritário. Julgamos importante 
afirmar que não se tratam de dois polos opostos, pois estas educações possíveis são produzidas dentro ou em meio à Grande Educação.

A produção conceitual de Deleuze e Guattari, portanto, é bastante complexa visto que não está posta como essência, não pontua como as coisas são. Ou seja, os conceitos, enquanto constelações informes, abertas e oriundas de um processo de criação - não de observação empírica - de modo algum encontram referentes na realidade ou na natureza. No máximo abrem margens e deixam vacúolos para que nós que fazemos uso deles os operemos de modo a colocar em movimentação o pensamento. Pensamento este que, como já dito anteriormente, não é inato à condição humana, mas precisa ser disparado, acionado a fim produzir o impensado.

Tal produção não se coloca em uma escala evolutiva e transcendente, visto que não é uma prática que constitui um além-mundo. Tais conceitos, enquanto instrumentos que podem ser atualizados quando nos servem de algum modo, pertencem, como dizem os próprios autores, a este mundo. É do e no presente - o aqui e agora - que falamos e temos condições de operar, de nos destacarmos como seres éticos e estéticos, produzindo modos de ser, estar e agir que, ainda que atravessados por estratificações, sejam permeados por linhas de fuga as quais façam correr o ponto estático, fixo.

Restabelecer o vínculo com o mundo constitui uma questão ética por excelência, uma questão de escolha. Enquanto seres no e do mundo, estamos diante de duas possibilidades: escolher a escolha ou escolher não escolher. Mas é a primeira que nos faz sujeitos éticos, pois só se escolhermos escolher é que seremos capazes de restabelecer nosso vínculo com o mundo. [...] é ela que nos torna capazes de dobrar o fora, de fazer a força afetar a si mesma, enfim, de subjetivar, de criar novas possibilidades de vida, novos modos de existência (LEVY, 2011, p. 131-132).

Procuremos, assim, aproximar dos modos de produzir pesquisas em Educação a prática do Corpo-sem-Órgãos (enunciada primeiramente pelo dramaturgo francês Antoni Artaud em sua conferência radiofônica Pour en finir avec le jugement de dieu [1947] e evidenciada posteriormente por Deleuze e Guattari no volume três de Mil Platôs), para quiçá propor algumas linhas, como intensidades de devir que atravessam e arrastam os estratos constituintes das mesmas, propondo, portanto, pesquisas que possam inventar educações possíveis.

Para Deleuze \& Guattari (2012a), a partir de Artaud, nunca se acaba de fazer um Corposem-Órgãos, porque ele é processo e não produto. Trata-se de um corpo "que é da ordem do acontecimento e da individuação, os quais não se definem por uma forma ou por um sujeito único, 
pleno, centrado, indivisível” (MOSSI, 2014). Destituído de sua organização prévia, passa a escolher o que nele passará a funcionar como órgão provisório, mais intensivo do que extenso.

Uma pesquisa-corpo-sem-órgãos seria uma pesquisa que não reconhece métodos e estruturas pré-datadas, mas que inventa a si e ao próprio pesquisador nesse processo, criando outras possibilidades de organização não-hierárquicas, "linhas de fuga como criações, desvios, fendas, vazamentos" (MOSSI, 2014). Seria uma pesquisa onde não se procura um campo a ser pesquisado, tampouco se aproxima ou se toma distâncias dele, porque pesquisador e pesquisado já constituem o seu próprio campo em uma relação não temporal/espacial, mas entre tais categorizações. Pesquisa que se orienta por linhas de escrita e imagens como linhas de vida que traçam cartografias complexas entre ver, falar e subjetivar-se sobre um Fora, sem, no entanto, abandoná-lo. Pesquisa que engendra o pensamento no próprio pensar e o movimenta, o violenta no sentido de buscar um ainda impensado.

Desse modo, o trabalho que temos buscado com as imagens em nossas investigações, é no sentido de que elas não reforcem conhecimentos apreendidos (ilustração), tampouco antecedam o que está sendo escrito (como se a escrita pudesse contar e dar conta de uma história nas/das imagens), mas que elas façam parte da construção textual como experiência autônoma que é revestida de outros tensionamentos junto à palavra escrita. Ou seja, nem escrita nem imagem valem por si sós, tampouco dependem uma da outra, mas são friccionadas e procuram lançar ao leitor modos de que ele adentre ao texto e crie pontes, trajetos e costuras próprias frente ao mesmo.

Pensar as imagens em uma pesquisa dessa forma trata-se de um trabalho desafiador, tanto para quem o produz, como para quem se dispõe ao convite de lê-lo. Há de se estar disposto a provocar uma torção no pensar de modo a colocá-lo em movimento de produção, não de reprodução. Apostar nas imagens como entes que possuem discursos próprios, significa escapar da lógica representacional ou da crença em uma essência escondida nas entrelinhas, a qual precisaria ser decifrada a fim de ser acessada, para encarar o pensamento como criação, como possibilidade. Ou seja, significa perguntar, junto de Deleuze e Guattari (1992a, p. 73) "que violência se deve exercer sobre o pensamento para que nos tornemos capazes de pensar, violência de um movimento infinito que nos priva ao mesmo tempo de poder dizer 'Eu'?'.

Quando uma imagem não reforça a ideia escrita e esta última não explica, não descreve a imagem apresentada, se trata de ir além de um Eu autônomo que acessa o conhecimento, para se tornar uma impessoalidade em devir no próprio movimento do pensar e do singularizar-se. 
Nesse sentido, para além da prática do Corpo-sem-Órgãos no contraponto de um organismo, Deleuze e Guattari (2012b) estabelecem em seu plano de pensamento um sistema linear no contraponto de um sistema pontual. O primeiro comporta duas linhas de base - uma horizontal e uma vertical (como uma trama, uma grade) - as quais formam no momento em que se encontram pontos fixos. Tais sistemas constituem-se como arborescentes (verticais, hierarquizados, estratificados), memoriais (buscam na memória e no passado explicação para o presente), molares (na contramão de intensidades moleculares), estruturais, de territorialização/reterritorialização. $\mathrm{O}$ máximo de deslocamento que ocorre nesse primeiro sistema é uma linha que pode ser traçada diagonalmente de um ponto a outro. O segundo sistema, linear, em contraponto (não em oposição) ao primeiro, tem por natureza liberar a linha diagonal, deixando-a correr livremente sem depender dos pontos ou do encontro entre verticais e horizontais.

Ainda nesse preâmbulo, os autores colocam em funcionamento tais conceitos/sistemas considerando que eles não são opostos, visto que ocorrem um no outro (assim como o Corpo-semÓrgãos em relação ao organismo, poderíamos dizer), e que não há músico, pintor, filósofo que não fabrique sistemas pontuais simplesmente com o objetivo de detoná-los, de fazer com que eles sofram uma vibração inesperada, um abalo sísmico (DELEUZE e GUATTARI, 2012b), uma desorganização. Criar um conceito, uma imagem ou uma melodia, seria, portanto, instaurar sistemas pontuais e ao mesmo tempo fazê-los detonar, criar organismos para que neles surjam Corpos-semÓrgãos como intensidades de criação.

A partir disso podemos destacar que, os modos de fazer pesquisa da qual tratamos neste texto, estando permeados por conceitos filosóficos e por imagens, ou seja, tratando da composição de tais entidades com o intuito de oferecer aos seus possíveis leitores, interstícios para que os mesmos adentrem ao texto, estabeleçam os nexos que lhes interessam e os transformem em outras coisas (inclusive nada), parece cumprir, para além de uma função de registro de um processo, também uma função ética e estética, na medida que institui modos de ser, estar, agir como pesquisador, sob certos aspectos metodológicos e epistemológicos.

\section{UMA INSPIRAÇÃO PARA O TRABALHO COM IMAGENS NAS PESQUISAS EM EDUCAÇÃO: O “LIVRO ILUSTRADO" MIL PLATÔS}

As imagens que se apresentam iniciando cada um dos chamados platôs de Mil Platôs, lá estão para muito além de meras ilustrações se pensarmos, é claro, a palavra 'ilustração' sob a conotação de reafirmar uma ideia escrita ou ainda, de servir de base para que a ideia escrita a descreva. Por uma questão de tradução, ou talvez até mesmo de uso dessa palavra por Deleuze, sem 
que o mesmo a tenha dado tal significado - como algo que fortalece o que estará escrito subsequentemente - o autor afirma em entrevista a Christian Descamps, Didier Eribon e Robert Maggiori (Libération, 23 de outubro de 1980) publicada em seu livro Conversações (1992b) de autoria conjunta a Guattari, que Mil Platôs se trata de um "livro ilustrado". Reproduzo abaixo parte da entrevista a fim de pensarmos melhor tal questão:

CHRISTIAN DESCAMPS - Como estão agenciados seus mil platôs? O livro Mille plateaux não se dirige somente a especialistas; [...]. Não está organizado em capítulos que desenvolveriam essências. Tomemos o sumário, está cheio de acontecimentos. 1914 é a guerra mas também a psicanálise do Homem dos lobos; 1947 é o momento em que Artaud encontra o corpo sem órgãos; [...]... As datas aqui são acontecimentos, marcas que não apontam para uma cronologia progressiva. Os platôs [...] estão repletos de acidentes...

GILLES DELEUZE - É um conjunto de anéis quebrados. Eles podem penetrar uns nos outros. Cada anel, ou cada platô, deveria ter seu clima próprio, seu próprio tom ou seu timbre. É um livro de conceitos. [...] Ocorre que os conceitos têm vários aspectos possíveis. Por muito tempo eles foram usados para determinar o que uma coisa é (essência). Nós, ao contrário, nos interessamos pelas circunstâncias de uma coisa: em que casos, onde e quando, como, etc.? Para nós o conceito deve dizer o acontecimento, e não mais a essência. [...] Cada anel ou platô deve pois traçar um mapa de circunstâncias, por isso cada um tem uma data, uma data fictícia, e também uma ilustração, uma imagem. É um livro ilustrado. Com efeito, o que nos interessa são os modos de individuação que já não são os de uma coisa, de uma pessoa ou de um sujeito: por exemplo, a individuação de uma hora do dia, de uma região, de um clima, de um rio ou de um vento, de um acontecimento. E talvez seja um equívoco acreditar na existência das coisas, pessoas ou sujeitos [...]. (DELEUZE; GUATTARI, 1992b, p. 37-38).

Conforme descrito, cada um dos platôs se inicia por uma imagem e não são chamados de capítulos como frequentemente estamos acostumados a ver nos livros, justamente porque não apresentam uma forma sequencial, tampouco essencial. Podem-se ler os platôs em qualquer ordem, ou sequer se faz necessário ler todos os platôs. Qualquer tentativa de totalidade será falha frente a esses cinco volumes, o que significa que, mesmo lendo todos os platôs não se chegará a um esgotamento dos conceitos criados e apresentados nos mesmos.

As imagens não se apresentam no início de cada platô como 'pistas' do que cada um irá tratar em sua forma escrita. Muitas vezes os autores nem sequer comentam algo sobre as imagens 
no decorrer da escrita ou, se o fazem, é sempre a partir delas, das potências que elas podem lançar a quem se dispõe a ler os livros. Poucas imagens são apresentadas com alguma legenda e, quando o são, tais enunciados estão distantes de cumprir um papel explicativo e/ou pedagógico. Cada platô é como uma constelação de referências, um tabuleiro de peças que não possuem encaixe, mas que dependem das associações do leitor a fim de experimentá-las. Sim, porque a leitura de Mil Platôs se trata de um exercício de experimentação, não de interpretação, tampouco de compreensão nos sentidos estritos desses termos.

Ao final da entrevista Deleuze volta a comentar a respeito das imagens que iniciam cada platô:

DIDIER ERIBON - Linhas, devires, acontecimentos... Eis-nos talvez de volta à questão do início, que dizia respeito às datas. [...] Datas fictícias, disse você, mas que remetem ao acontecimento, às circunstâncias, [...].

GILLES DELEUZE - Que cada platô esteja datado, com uma data fictícia, não tem importância maior do que o fato de que esteja ilustrado, ou que comporta nomes próprios.

O estilo telegramático tem uma potência que não vem só de sua brevidade. [...].

Mas é interessante se a escrita por si mesma chega a dar esse sentido de iminência, de algo que vai suceder ou acaba de se passar nas nossas costas. Os nomes próprios designam forças, acontecimentos, movimentos e motivações, ventos, tufões, doenças, lugares e momentos, muito antes de designar pessoas. [...] As datas não remetem a um calendário único homogêneo, mas a espaços-tempos que mudam a cada vez... Tudo isso constitui um agenciamento de enunciação [...]” (DELEUZE; GUATTARI, 1992b, p. 48).

Este sentido de iminência descrito pelo autor, ou seja, de algo que é iminente no sentido de alguma coisa que está por acontecer ou que acaba de ocorrer, nos dá o tom de Mil Platôs: um livro que persegue linhas de fuga da representação de uma realidade pré-datada, pré-concebida, préimaginada. Nessa seara, uma imagem ilustrativa enquanto decalque de uma ideia escrita ou que sirva de base para uma narrativa que seja ela própria da esfera imagética se faz no mínimo impossível, ou ao menos não daria conta da complexidade que propõem os platôs de Deleuze e Guattari.

No coletivo Sábados com Deleuze temos no trabalho com imagens em Mil Platôs uma forte inspiração para as pesquisas que temos produzido com e a partir de imagens. Nos são caras as possibilidades de produzir uma pesquisa formada por "anéis quebrados" que se interpenetram, 
como aponta Deleuze na entrevista mencionada, mas que não necessariamente constituem uma totalidade ou dizem de uma possível essência quando estão unidas. Cada parte é mais uma região de intensidades, uma circunstância atravessada por escritas e imagens como acontecimentos de pesquisa, onde algo já se passou ou está prestes a acontecer, visto que não consegue nunca fixar uma única realidade exata a ser "representada" pelos ditos e vistos da investigação.

\section{O QUE SE PODE, A PARTIR DAQUI, APRENDER SOBRE INSCREVER IMAGENS NA ESCRITA E PRODUZIR PESQUISAS (EM EDUCAÇÃO)?}

O que buscamos até então neste artigo, embora utilizando certas exemplificações, não foi apresentar as pesquisas na área da educação como elas estão sendo, como tratam os conceitos com os quais operam, de que modo inscrevem as imagens no texto ou como apresentam seus produtos finais. Tampouco como elas devem ou deveriam ser. Preferimos pensar, a partir do plano de pensamento ofertado por Deleuze e Guattari em algumas de suas obras, como os trabalhos investigativos no campo educacional podem vir a ser e, sobretudo, como têm sido produzidas em nosso coletivo de estudo Sábados com Deleuze.

Ou seja, sob pena de utilizar todo o escopo do texto para criticar alto que, ao nosso ver, muito pouco contribuiria com o campo, optamos por produzir uma perspectiva possível, que se constitui entre outras, para assim olhar o modo como pode ser produzida e escrita de textos investigativos e como as imagens podem ser inscritas nos mesmos.

Mais uma vez, Deleuze e Guattari (1992a, p. 42) nos auxiliam a pensar tal ação, assegurando que

Criticar é somente constatar que um conceito se esvanece, perde seus componentes ou adquire outros novos que o transformam, quando é mergulhado em um novo meio. Mas aqueles que criticam sem criar, aqueles que se contentam em defender o que se esvaneceu sem saber dar-lhe forças para retornar à vida, eles são a chaga da filosofia.

Embora este texto não se trate de uma produção especificamente no campo da filosofia, mas faz uso da mesma para pensar o campo da educação e das pesquisas produzidas no mesmo as quais se utilizam de imagens, acreditamos que seria vago e improdutivo demais uma crítica vazia, sem proposições palpáveis. É nesse sentido que podemos nos perguntar: o que se pode, mediante ao que foi apresentado até então, aprender e colocar em prática a respeito de inscrever imagens na escrita e produzir pesquisas, especialmente no campo da educação?

Com a prática do Corpo-sem-Órgãos podemos pensar que organismos temos obedecido, tomado como modelo e, ao mesmo tempo, obstruído, rompido, desorganizado com nossas 
investigações? Que passagens temos aberto para que intensidades afetivas arrastem algumas das estruturas rígidas e das hierarquias metodológicas que instituem e institucionalizam corpospesquisas e corpos-pesquisadores em educação?

Com os sistemas pontuais e lineares podemos pensar de que modo nos debruçamos sobre nossos campos de investigação e nos movimentamos sobre eles. De modo a nos mantermos fixos em um ponto, condicionados pelas instâncias verticais e horizontais que produzem diagonais rígidas? O fazemos com o intuito de liberarmos essa diagonal a fim de produzir outras possibilidades operando com os conceitos e as imagens em nossos trabalhos, ou mesmo de apresentarmos os produtos finais dos mesmos?

Com as imagens de Mil Platôs, podemos pensar os modos como temos utilizado, inscrito as imagens em nossa escrita. É de modo a reforçar o que estamos escrevendo, escrevendo sobre as imagens, explicando-as, descrevendo-as, restringindo uma interpretação plausível como se fosse única? É de modo a violentar o pensamento do leitor e o nosso próprio, possibilitando assim o desafio de criar pontes, de estabelecer entremeios, sulcar túneis e construir caminhos entre palavra escrita e imagem, ambas tensionadas, friccionadas, problematizadas como experiências múltiplas?

Sem dúvida há instâncias a serem respeitadas, há organismos e linhas verticais e horizontais de toda ordem que nos estabelecem a diagonal como única possibilidade de trânsito. Este trânsito é aquele dos caminhos já deveras pisados, dos formatos prontos que não nos desafiam a inventar novos e impensados, é aquele que tem uma predileção pelo decalque, pela reafirmação de ideias, pelas explicações facilitadas e descomplexizantes, como se fossem as únicas aceitáveis, como se fossem melhores e mais apuradas ou simplesmente como se nos levassem a uma terra prometida do conhecimento e do saber que nos esperam, como o pote de ouro no final do arco-íris.

Contudo, há sempre uma linha errante possível, uma linha que se libera da diagonal e que, não dependendo mais de horizontais e verticais fixas, produz outros caminhos, inventa outros (novos e impensados) formatos, mantém a complexidade não como algo dificultoso, mas como algo que entende que as realidades são repletas de multiplicidades e trânsitos inapreensíveis. Essa linha louca, móvel, constituída por uma velocidade infinita, não tem ponto de chegada prometido porque é, nela mesma, o resultado e a busca. Produz saberes e aprendizagens justamente porque instaura aquilo que não se pode acabar de saber nem se aprender.

Deleuze traz de Foucault o conceito de Fora e, ainda que de algum modo ligado a este último, dá a ele outra composição, outra roupagem. Segundo Levy (2011), em Foucault, o Fora está associado à despersonalização do sujeito, ao pensamento que se mantém fora de toda subjetividade 
já formada. Já, “em Deleuze, a experiência do fora aparece sobretudo nas discussões sobre o pensar e sobre arte" (LEVY, 2011, p. 99).

Deleuze pontua que tanto o pensamento (disparado pela arte) quanto a própria arte (que violenta o pensamento) pressupõem uma movimentação que nos tira do senso comum, que nos arrasta para um campo sem certezas fixas nem verdades universais. Sem dúvida, atualmente, tal afirmação pode e deve ser ampliada, visto que não só a arte (institucionalizada) possui essa capacidade frente ao pensamento. Em tempos como os nossos (tempos que, por sinal, Deleuze não chegou a conhecer), onde dispomos de inúmeros aparatos visuais e tecnológicos, com possibilidades de trânsito nunca antes vistas, parece-nos que não só a arte em si oferece tais impactos.

Contudo, a partir disso podemos nos questionar: é possível escrever uma pesquisa pelo Fora? Ou seja, é possível - pensando no conceito de Fora a partir de Deleuze - produzir uma pesquisa que ofereça disparadores que deflorem o pensamento tanto do leitor como de quem a produz? Como as imagens seriam inscritas nessa escrita?

Neste texto buscamos pensar que sim, vislumbrando no trabalho de nosso coletivo de estudo algo que tem procurado se sustentar sobre tais aportes, deixando-se atravessar por eles. Há talvez os que se perguntem ao final desse texto, mas como afinal tais pesquisas se constituem? Sobre que materialidades? Há algo além de mera teorização "vazia"?

Primeiramente há que se destacar que tais investigações não percebem de modo separado teoria e empirismo. Sendo o Fora constituído pelo "domínio das forças, das singularidades selvagens, da virtualidade, onde as coisas não são ainda, onde tudo está por acontecer" (LEVY, 2011, p. 102), tais separações binárias não se fazem cabíveis. Conforme Gallo (2010, p. 56)

[...] à teoria não compete explicar a prática ou mesmo possibilitá-la, assim como não compete à prática alimentar a teoria ou manifestá-la na luta social. É impossível dissociá-las, sobretudo porque, se saímos do âmbito da representação, as totalizações já não fazem mais sentido e deixam inclusive de ser possíveis.

Quando escrevemos sobre algo, ou ainda quando colocamos nossas investigações em movimento através da escrita e das imagens que produzimos/utilizamos, estamos para além de representar nosso campo de pesquisa ou dar conta do mesmo em forma de um relato. Estamos sim constituindo o próprio campo, sulcando-o. Fazemos de nós mesmos o campo onde a pesquisa se passa, por onde atravessam e se transformam as teorias. 
Reconhecemos que pensar a pesquisa e construí-la desse modo se faz na contramão de grande parte do que vem sendo produzido. Mas justamente a experimentação do Fora não ocorre sem ser, sobretudo, um processo de resistência (LEVY, 2011, p. 100), "uma luta da língua menor contra seu modo maior, das tribos contra o Estado, das minorias contra a maioria”. Poderíamos incluir aí dos Corpos-sem-Órgãos contra os organismos, dos sistemas lineares contra os sistemas pontuais. Retornamos assim ao começo: dar outras velocidades ao pensamento, fazê-lo percorrer mapas não representacionais, mas inventivos, produtivos de percursos impensados; tensionar o que é dito (através da escrita) e o que é visto (através das imagens), para assim propor outras dobras sobre o Fora, outras linhas de subjetivação; liberar as diagonais presas em sistemas pontuais fixos, construir sistemas pontuais simplesmente para fazê-los detonar; perseguir uma escrita pelo Fora enquanto processo de resistência, enquanto busca por um Corpo-sem-Órgãos teórico e metodológico dos modos de produzir conhecimento no campo da educação. 


\section{REFERÊNCIAS}

ARTAUD, A. Para acabar com o julgamento de Deus (Pour en finir avec le jugement de dieu [1947]). In: WILLER, C. [tradução, seleção e notas]. Escritos de Antonin Artaud. Porto Alegre: L\&PM, 1983. p. 145-162. AUTOR. (informação que implicaria em quebra de anonimato) Tese de doutorado. Programa de Pós-Graduação em (informação que implicaria em quebra de anonimato) (Linha de Pesquisa (informação que implicaria em quebra de anonimato)), Universidade (informação que implicaria em quebra de anonimato), 2014.

AUTOR; AUTOR. (informação que implicaria em quebra de anonimato). In: (informação que implicaria em quebra de anonimato), 2013, p. 3217-3231. Disponível em: (informação que implicaria em quebra de anonimato). Acesso em julho de 2017.

AUTOR. de. (informação que implicaria em quebra de anonimato) Revista (informação que implicaria em quebra de anonimato) v. 24 n. 56 p. 443-454 maio/ago., 2015.

CORAZZA, Sandra Mara. Contribuições de Deleuze e Guattari para a pesquisa em Educação. Revista Digital do LAV, Santa Maria (RS), ano 5, n. 8, 2012, p. 01-19. Disponível em: <http://cascavel.ufsm.br/revistas/ojs2.2.2/index.php/revislav/article/view/5298>. Acesso em: mar. 2013.

DELEUZE, Gilles; GUATTARI, Felix. Mil platôs: capitalismo e esquizofrenia, vol. 1 [tradução de Ana Lúcia de Oliveira, Aurélio Guerra Neto e Celia Pinto Costa]. 2. ed. São Paulo: Ed. 34, 2011.

Mil platôs: capitalismo e esquizofrenia, vol. 3 [tradução de Aurélio Guerra Neto, Ana Lúcia de Oliveira, Lúcia Cláudia Leâo e Suely Rolnik]. 2. ed. São Paulo: Ed. 34, 2012a.

Mil platôs: capitalismo e esquizofrenia, vol. 4 [tradução de Suely Rolnik]. 2. ed. São Paulo: Ed. 34, 2012 b.

O que é a filosofia? Rio de Janeiro: Ed. 34, 1992a.

Conversações. São Paulo: Ed. 34, 1992b.

GALLO, Silvio. Filosofia da diferença e educação: o revezamento entre teoria e prática. In: CLARETO, Sônia Maria; FERRARI, Anderson. Foucault, Deleuze e Educação. Juiz de Fora: Ed. UFJF, 2010. p. 49-63.

LEVY, Tatiana Salem. A experiência do fora: Blanchot, Foucault, Deleuze. Rio de Janeiro: Civilização Brasileira, 2011. MOSSI, Cristian Poletti. Um corpo-sem-órgãos, sobrejustaposições: quem a pesquisa [em educação] pensa que é? Tese de doutorado. Programa de Pós-Graduação em Educação (Linha de Pesquisa Educação e Artes). Universidade Federal de Santa Maria, 2014.

MOSSI, Cristian Poletti; MOSSI, Marilda Oliveira de. In: Ecossistemas Estéticos: Anais do $22^{\circ}$ Encontro Nacional de Pesquisadores em Artes Plásticas - Anpap, Belém/PA, 2013, p. 3217-3231. Disponível em: <http://www.anpap.org.br/anais/2013/ANAIS/simposios/07/Cristian\%20Poletti\%20Mossi\%20e\%20Marilda\%20Oliveir a\%20de\%20Oliveira.pdf> Acesso em: julho de 2017.

OLIVEIRA, Marilda O. de. Como produzir clarões nas pesquisas em educação? In: Revista Educação Pública (Cuiabá, UFMT), v. 24 n. 56 maio/ago, 2015, p. 443-454. 


\section{RESUMO}

O artigo trata dos modos como o Coletivo de Estudos 'Sábados com Deleuze' tem trabalhado com textos e imagens em suas pesquisas entre arte e educação - não como reforço ou decalque de realidades fixas, mas como disparadores de tramas discursivas que excedem, ampliam, tensionam visualidades e escritas formuladoras de multiplicidades experimentativas. Também busca, a partir do conceito de Fora em Deleuze enquanto singularidade no pensamento que se mantém distante de toda e qualquer subjetividade formada acionar formas de fazer pesquisas menores, ou seja, marginais em relação ao que o artigo nomeia de acordo com seu campo teórico como Pesquisas Majoritárias.

Palavras-chave: Imagem; Escrita; Pesquisa em Educação.

\section{"SATURDAYS WITH DELEUZE": IMAGES ON WRITINGS AND WRITING THROUGH THE OUTSIDE BETWEEN ART, RESEARCH AND EDUCATION}

\section{ABSTRACT}

The article addresses how the Study Group 'Saturdays with Deleuze' has been working with texts and images in its research on art and education - not as a reinforcement or decal of fixed realities, but as triggers of discursive plots that surpass, amplify, tense visualities and writings formulating experimental multiplicities. It also seeks, based on Deleuze's Outside concept - as a singularity in thinking that keeps itself apart from any and all formed subjectivity - to trigger ways of doing smaller, that is, marginal research in relation to what the article names, according to its theoretical field, as Major Research.

Keywords: Image. Writing. Research in Education.

\section{"SÁBADOS COM DELEUZE": IMÁGENES EN LA ESCRITURA Y ESCRIBIR POR EL FORA ENTRE EL ARTE, LA INVESTIGACIÓN Y LA EDUCACIÓN}

\section{RESUMEN}

El artículo trata del modo como el Colectivo de Estudios 'Sábados com Deleuze' ha trabajado con textos e imágenes en sus investigaciones entre arte y educación - no como refuerzo o decalque de realidades fijas, y sí como disparadores de líneas discursivas que exceden, amplían, tensan visualidades y escrituras formuladoras de multiplicidades experimentacionales. También quiere, a partir del concepto de Fora en Deleuze - mientras singularidad en el pensamiento que se mantiene alejado de toda y cualquier subjetividad formada - accionar formas de hacer investigaciones menores, o sea, marginales en relación al que el artículo llama de acuerdo con su campo teórico como Investigaciones Mayoritarias.

Palabras clave: Imagen. Escritura. Investigación en Educación. 